\title{
Ephemeral stream dynamics, land cover changes and climate variability in the marginal grabens of the northern Ethiopian Rift Valley'
}

\author{
Biadgilgn Demissie \\ Department of Geography, Ghent University
}

\begin{abstract}
This study focused on ephemeral streams morphodynamics and their relation with hydro-climatic and bio-physical characteristics in their headwater and graben floors in the marginal grabens along the northern Ethiopian Rift Valley. The Raya graben was taken as a case study area, which is the largest marginal graben in northern Ethiopia. The link between rainfall variability and land cover changes shows that there was a negative correlation between precipitation and deforestation which implies that an increase in precipitation decreases deforestation deterring the peasants from tree cutting. Regarding the relationship between upper catchment characteristics and river morphology, results show that upper catchment area is the most important controlling factor of the length of and the area occupied by the rivers in the graben bottom. A simple hydraulic analysis based on the change of specific discharge as the river flow approaches the bridges demonstrates that the abrupt change in channel width as the river approaches the bridge is the main cause of the thick deposition and, consequently, of the increased frequency of overbank floods upstream of the road bridges in the study area. The results related to channel bank erosion capacity of flash floods show that all the peak discharges were equally important in triggering channel bank erosion. Concomitantly, vegetated channels are much more resistant to channel bank erosion than non-vegetated banks. Land changes in graben bottoms dictate that the changes are not simply related to a distributary river system but that human intervention (e.g., the conversion of bushland and forests into cropland, settlement on alluvium, and avoidance of losing farmland to other land units) and natural vegetation regeneration (e.g., alluvial deposits into shrubland) are also important. Overall, the study suggests that to control the morphodynamics of the ephemeral rivers and their impact on farming activities in the graben bottom, catchment rehabilitation activities need to focus both on the upper catchment and the river channels in the graben bottom.
\end{abstract}

Key words: ephemeral streams, land change, graben, Rift Valley, land cover, climate variability 


\section{The problem statement and study context}

The marginal grabens in the northern branch of the Ethiopian Rift Valley are typical semi-arid depositional basins onto which several ephemeral rivers draining the graben shoulders transfer large quantities of sediment through the main river stems and wide distributary systems (Biadgilgn et al., 20I6). They are characterized by steep escarpments and gentle graben floors (Fig. I). As depositional basins characterized by flash floods and dynamic rivers (in terms of morphology) draining into it, there are social and environmental problems that prevail. Due to flooding, the destruction of settlement areas (villages and towns) and farmland is frequent. Besides, the conversion of cropland into sandy flood plains, active channels, and shrubland creates situations leading to parafluvial and orthofluvial belts along rivers (Lorang and Hauer, 2006). The parafluvial landforms consist of areas of the floodplain that are frequently flooded at near bank full stage and are dominated by scour, erosion and bedload deposition, whereas the orthofluvial landforms are characterized by plant succession (e.g., grasses and shrubs) and are inundated by annual flood events.

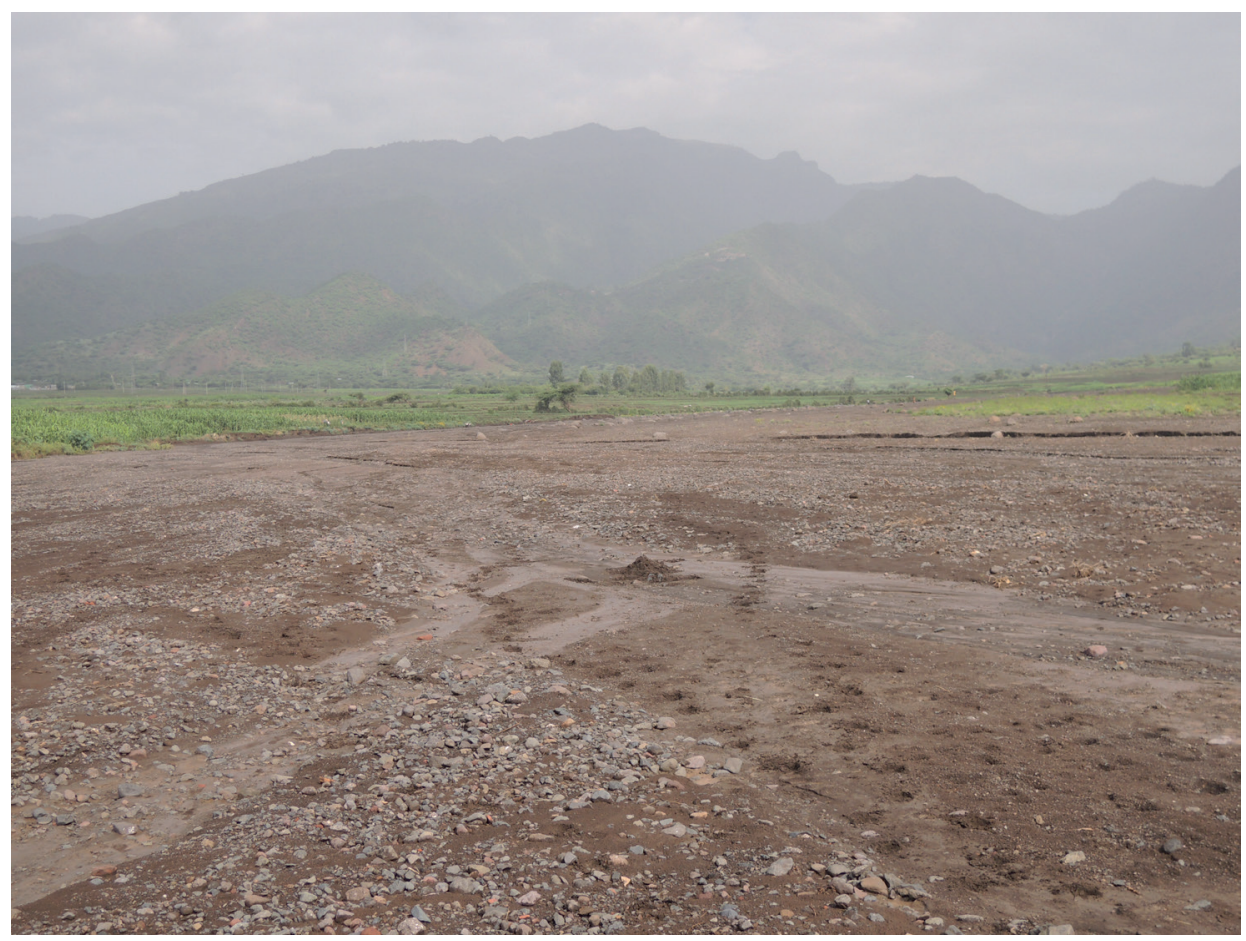

Figure 1: The western steep escarpments (at the back of the photo) and the gentle graben bottom in which the ephemeral river drains (at the middle and front of the photo) in the Raya graben. Hara river (August 2013) 
Albeit land degradation affects ephemeral river morphodynamics (Seeley et al., 2003; Frankl et al., 20II) there is little research that dealt with land degradation, rehabilitation and sedimentation. A few of them dealt with sediment deposition and yield related to the rehabilitation activities under practice and stream morphological changes (Descheemaeker et al., 2006; Nyssen et al., 2008, 2009; Frankl et al., 20II, 2013). Other studies, such as Tesfaalem et al. (2015, 20I6) focused on mountain streams and land use and cover changes in the escarpments. Most of these studies, however, focused on the highland stream channel morphodynamics. In the marginal graben bottom and pertaining the ephemeral streams, there are some studies carried out by Billi (2007, 2008, 20II, 20I6) which investigated stream flow, channel morphology and sedimentation (dynamics, transport). Worldwide there are many other researches related to ephemeral streams (e.g., Billi and Tacconi, I985; Dunkerley, I992; Laronne and Reid, I993; Tooth, 2000, 2005) but data about the relationship between headwater, the morphological changes downstream and their subsequent relationship between the distributary systems and land changes are scarce. Hence, the overall research question of this study was "what is the morphological interaction of ephemeral rivers characterized by a contrasting environment between their upper catchments and the landscape in the graben bottom in drylands?".

From a regional point of view, this research is one step forward to solve data scarcity related to ephemeral rivers (their morphological behavior, their interaction with their headwaters and their implication for land use/cover) in dryland areas where data availability for research and decision making is a challenge. Similarly, the research has a broad contribution to scientific knowledge in terms of providing new findings related to ephemeral rivers morphodynamics in semi-endorheic graben system with a contrasted topography (the steep escarpment and the more gentle graben bottom) in drylands. This research generates new knowledge on diverse aspects of ephemeral rivers in a graben bottom and their catchment characteristic in escarpments. These include: (i) the impact of climate variability on land cover changes in dryland escarpments, (ii) ephemeral river length and area in a graben bottom in relation to bio-physical (e.g., vegetation cover, catchment area, slope gradient) characteristics of their headwaters, (iii) the relation between peak floods and channel width change and the role of riparian vegetation to bank resistance, (iv) the role of bridge narrowing on thick sedimentations at bridge reaches in a graben bottom, and (v) the role of ephemeral river distributary systems to land unit changes in a landscape in a graben bottom.

\section{Methodology}

The Raya graben was taken as a case study area, which is the largest marginal graben in northern Ethiopia. The study was conducted in different spatial scales. For the analysis of the climate variability, land cover change and stream morphodynamics, both field measurements and remote sensing data were needed. For land and vegetation cover analysis along the escarpment, Landsat imageries that were captured since 1986 were used. In order to obtain short term but spatially representative precipitation records, rain gages were operated in both the escarpment and the graben floor of the study area. 
Satellite-derived Rainfall Estimates (RFEs) obtained from NOAA-CPC were calibrated to map rainfall variability between 1996 and 20I4. Peak discharges were measured in the 2013 and 2014 rainy seasons (July to September) using crest stage gages. Measurements related to sediment deposition in channel reaches in the graben bottom were made in 22 river reaches in 2015. Aerial photographs of 1965 and 1986 , and SPOT satellite images were used for the analysis of stream morphodynamics for the last five decades.

\section{Findings and discussions}

Land cover change in relation to rainfall variability on the source areas

The results of the land cover analysis show a decline in cultivated land from $40.6 \%$ to $35.4 \%$ between 2000 and 20I4. The proportion of woody vegetation which incorporates forest, bushes and Eucalyptus plantation remained constant at $53.5 \%$ across the escarpment. These changes did not occur linearly, however (Annys et al., 20I6). During each five-year period (between 2000 and 20I4), land cover change took place over $35 \%$ of the western escarpment of the study area.

Regarding the link between rainfall variability and land cover change, a linear regression analysis shows that there was no correlation between 'forest expansion' or 'conversion to bushland' and Pdiff at full period between 2000 and 20I4. But, there was a negative correlation between precipitation and deforestation which implies that an increase in precipitation decreases deforestation deterring the peasants from tree cutting. In periods when precipitation is low, the peasants cut trees and tree branches to sustain their living. Hence, it can be noted that the impact of precipitation is visible in terms of decreasing deforestation and vegetation intensification. There was also a positive correlation between precipitation and the expansion of farmland. Concomitant to this, in the drier period between 2000 and $\mathbf{2 0 0 5}$, there was a decrease in farmlands. This implies that increase in precipitation enhances farming activities and a decrease in precipitation has an inverse effect. This may be because the farmers abandon marginal farmlands during dry periods.

\section{Stream morphodynamics and controlling factors}

In order to investigate the link between upper catchment vegetation cover and the morphology of the rivers in the graben bottom, NDVI maps were prepared for the years I986, 2000, 2005 and 2010. Other physical characteristics of the upper catchments, namely, catchment area, compactness, slope gradient, and extremely degraded areas were defined. The slope gradient in the graben bottom was also considered. Results show that upper catchment area is the most important controlling factor of the length of and the area occupied by the rivers in the graben bottom. Only the trend of the NDVI and the length of the rivers tend to be inverse where it indicates that an increase in vegetation cover reduces the length of the river in the graben bottom. In this regard, vegetation cover can be considered as a secondary variable to influence river morphodynamics in the graben bottom. 
In recent years, the bridges of the road that crosses the Raya graben bottom along the foot of the escarpment experience high sedimentation that triggered the clogging of the bridges. To understand what caused the thick sedimentation and the bridge clogging, its link to bio-climatic and hydro-geomorphic characteristics of the source area was investigated. Results show that the highest NDVI values were recorded in the headwaters in the time interval from 2000 to 20I4, the decade during which the study bridges experienced excessive sedimentation, a sediment thickness of up to r.6 m under bridges that were built in 2002. Although there is no data about channel hydraulic geometry changes in the study area, the weak control of vegetation cover could perhaps be related to the depositions of colluviums and alluviums at the lower parts of the escarpment (Fig. 2, $\mathrm{C}$ and $\mathrm{D}$ ) that took place before the I980s, during the time when rehabilitation activities were little/none (Tesfaalem et al., 20I6). Hence, in recent times the remobilized sediments may have been flushed further down to the bridge and downstream reaches due to clear water effect (Kondolf, I997; Boix-Fayos et al., 2007) (Fig. 2, E and D).

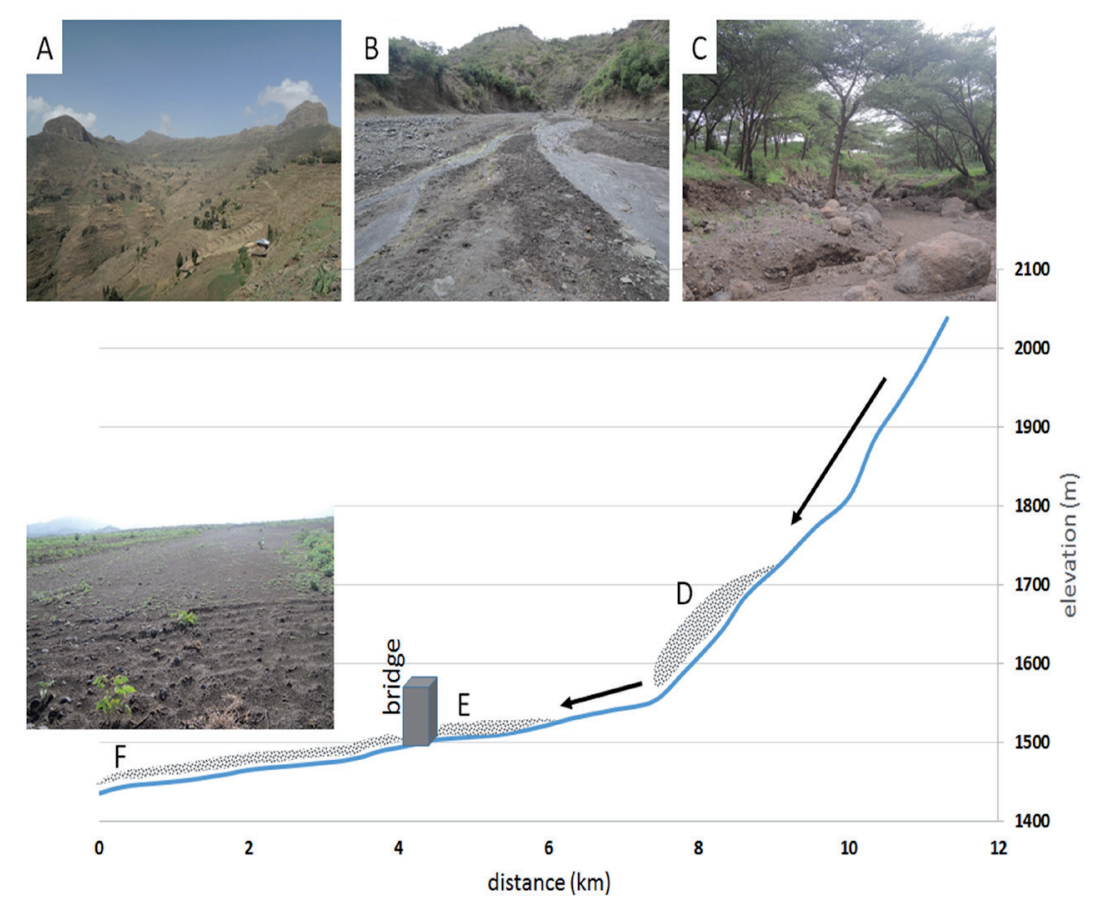

Figure 2: Sediment mobilization from the upper part of the escarpment (A); direct sediment transport at the middle part of the escarpment (B); deposition of alluviums (C, D) and possible recent incisions $(C)$ in the lower parts of the escarpment; bridges that influence distribution of sediment deposition in the graben bottom $(\mathrm{E})$; sediment depositions in the distributary system and farmland farther from the bridges in the graben bottom (F). (A, mount Abohoy, and B, around Azezsamba in Lasta), and May 2015 (C, escarpment foot of Etu river, and F, downstream reach of Harosha river in the graben bottom) 
A simple hydraulic analysis based on the change of specific discharge as the river flow approaches the bridges, substantiated by the general river equation of Lane (I955), demonstrates that the abrupt change in channel width as the river approaches the bridge is the main cause of the thick deposition and, consequently, of the increased frequency of overbank floods upstream of the road bridges in the study area. The width of a bridge affects the hydraulic performance of the bridge; wider bridges are more efficient than narrower ones. It is preferred to keep the ratio of upstream channel width and bridge width (Wc/Wb) below I (Hamill, r999).

The channel bank erosion capacity of flash floods was investigated in the rainy season (July to September) of two years (2013 and 2014) in two rivers (Etu and Hara). The results show that all the peak discharges were equally important in triggering channel bank erosion. A continuous widening throughout the rainy season was also observed. Similarly, our observation that vegetation on the banks of a river reduces bank erosion is in line with earlier studies confirming that non-vegetated channels are much wider than channels with riparian vegetation (Beeson and Doyle, I995; Ikeda and Izumi, I990; Huang and Nanson, 1997). In this study similar results are found: channel banks without riparian vegetation being easily eroded by floods as compared to the vegetated ones. Hence, in the study area, instead of incurring costs for immediate and unsustainable measures, such as sand embankments and gabion structures, enhancing riparian vegetation could be a low social and financial cost strategic measure to ensure reduced impacts of the ephemeral rivers on farming activities and settlements.

\section{River distributary systems and land changes in the graben bottom}

The roles river distributary systems play in their surrounding landscape due to their dynamics is important (Lorang and Hauer, 2006) though it seems scarce in literature. The objective was therefore to analyze the land changes in the Raya graben bottom related to the dynamics of river distributary systems for the last five decades, and investigate the cyclicity of transitions in the landscape. The study shows that large farmland areas were transformed into active channel in the period between 1965 and 1986 , which is a period of river expansion due to high expansion of the distributary system of the river. The time between I986 and 2007 was a period of vegetation succession. This implies that the river abandons parts of its active channel to develop to alluvial deposits and again to grassland or shrubland. This gives a ground for vegetation to naturally succeed on the land abandoned by the river. From the transitions we understand that the changes are not simply related to a distributary river system but that human intervention (e.g., the conversion of bushland and forests into cropland, settlement on alluvium, and avoidance of losing farmland to other land units) and natural vegetation regeneration (eg., alluvial deposits into shrubland) (Salo et al., I986) are also important. 


\section{Conclusion}

From the study of 20 catchments on the link between upper catchment bio-physical characteristics and river morphology in graben bottoms, we conclude that catchment area is the most important controlling factor for the length of and the area occupied by the ephemeral rivers in the graben bottom. Vegetation cover can be counted as a secondary controlling factor. In the study of bridge sedimentation, a simple hydraulic analysis demonstrates that the abrupt change in channel width due to bridges is the main cause of bridge sedimentation. Hence, it is recommended that the width of the bridges should be at least as wide as the upstream channel reaches. Similarly, the study on bank erosion resistance suggests that protecting embankments by prohibiting removal of any natural vegetation (by humans or by livestock) is key for stabilizing river banks. The distribution of land units in a landscape surrounding a river distributary system in a graben bottom indicates that the land unit changes are not only related to a distributary river system but also that human intervention and natural vegetation regeneration are important.

Overall, the study suggests that to control the morphodynamics of the ephemeral rivers and their impact on farming activities in the graben bottom, catchment rehabilitation activities need to focus both on the upper catchment and the river channels in the graben bottom. In order to fully understand the behavior of the ephemeral rivers and their impact on farming systems and other economic activities, further studies should be carried out on the hydraulic hazards, sediment volumes in distributaries and farmlands, and their implications on livelihood.

\section{References}

Beeson CE, Doyle PF. (I995). Comparison of bank erosion at vegetated and non-vegetated channel bends. Water Resour. Bull. 31: 983-990.

Biadgilgn Demissie, Billi P., Frankl A, Mitiku Haile, Nyssen J. (2016). Excessive river sedimentation at bridges in the Raya graben (northern Ethiopia). Land Degradation and Development, resubmitted, online early view. DOI: I0.1002/ldr.2572.

Billi P, Tacconi P. (1985). Morfologia sedimentologia e dinamica fluviale di due corsi d' acqua effimeri della Somalia settentrionale. Quaderni di Geologia della Somalia 8: 43-86.

Billi P. (2007). Morphology and sediment dynamics of ephemeral stream terminal distributary systems in the Kobo Basin (northern Welo, Ethiopia). Geomorphology 85: 98-II3.

Billi P. (2008). Bedforms and sediment transport processes in the ephemeral streams of Kobo basin, Northern Ethiopia. Catena 75: 5-17.

Billi P. (20II). Flash flood sediment transport in a steep sand-bed ephemeral stream, Int. Jour. Sediment Res. 26 (2): 193-209.

Billi P. (20I6). Channel processes and sedimentology of a boulder-bed ephemeral stream in the western Afar margin, Zeitschrift für Geomorphologie 6o (I): 35 - 52.

Descheemaeker K, Nyssen J, Poesen J, Raes D, Mitiku H, Muys B, Deckers S. (2006). Runoff on slopes with restoring vegetation: A case study from the Tigray highlands, Ethiopia. Journal of Hydrology 33I: 219-24I.

Dunkerley DL. (1992). Channel geometry, bed material and inferred flow conditions in ephemeral stream systems, Barrier Range, western N.S.W. Australia. Hydrol. Process. 6: 417-433.

Frankl A, Nyssen J, De Dapper M, Mitiku H, Billi P, Munro RN, Deckers J, Poesen J. (20II). Linking longterm gully and river channel dynamics to environmental change using repeat photography (Northern Ethiopia). Geomorphology I29: 238-25I. 
Frankl A, Poesen J, Mitiku H, Deckers J, Nyssen J. (2013). Quantifying long-term changes in gully networks and volumes in dryland environments: The case of Northern Ethiopia. Geomorphology 20I: 254-263.

Hamill L. (1999). Bridge hydraulics. E \& FN SPON, London.

Huang HQ, Nanson GC. (1997). Vegetation and channel variation: A case study of four small streams in southeastern Australia. Geomorphology I8: 237-249.

Ikeda S, Izumi N. (1990). Width and depth of self-formed straight gravel-bed rivers with bank vegetation. Water Resour. Res. 26:2353-2364.

Lane EW. (1955). The importance of fluvial morphology in hydraulic engineering, Proceedings of the American Society of Civil Engineers 8I: I-I7.

Laronne JB, Reid I. (1993). Very high rates of bedload sediment transport by ephemeral desert rivers. Nature 366: I48-I50.

Lorang MS, Hauer FR. (2006). Fluvial geomorphic processes: In Hauer FR, and Lamberti GA (editors). Methods in Stream Ecology, 2nd Edition. Elsevier, Amsterdam.

Nyssen J, Poesen J, Descheemaeker K, Nigussie H, Mitiku H, Moeyersons J, Frankl A, Govers G, Munro N, Deckers J. (2008). Effects of region-wide soil and water conservation in semi-arid areas: The case of northern Ethiopia. Z. Geomorph. N.F. 52(3): 29I-3I5.

Nyssen J, Clymans W, Poesen J, Vandecasteele I, De Baets S, Nigussie H, Naudts J, Amanuel H, Moeyersons J, Mitiku H, Deckers J. (2009). How soil conservation affects the catchment sediment budget - a comprehensive study in the north Ethiopian highlands. Earth Surf. Process. Landforms 34: I2I6-I233.

Salo J, Kalliola R, Hakkinen H, Makinen Y, Niemela P, Puhakka M, Coley PD. (I986). River dynamics and the diversity of Amazon lowland forest. Nature 322: 254-258.

Seeley M, Henderson J, Heyns P, Jacobsen P, Nkale T, Nantanga K, Schachtschneider K. 2003. Ephemeral and Endoreic River Systems: Relevance and Management Challenges. In Turton, A.R., Ashton P, Cloete E. (Eds.) Transboundary Rivers, Sovereignty and Development: Hydropolitical Drivers in the Okavango River Basin. Pretoria and Geneva: African Water Issues Research Unit (AWIRU) and Green Cross International (GCI).

Tesfaalem GA, Frankl A, Mitiku H, Amanuel Z, Nyssen J. (2015). Determinants of peak discharge in steep mountain catchments - Case of the Rift Valley escarpment of Northern Ethiopia. Hydroloy 529: 1725-1739.

Tesfaalem GA, Frankl A, Mitiku H, Nyssen J. (20I6). Catchment rehabilitation and hydro geomorphic characteristics of mountain streams in the western Rift Valley escarpment of northern Ethiopia. Land Degraddation \& Development. 27: 26-34.

Tooth S. (2000). Downstream changes in dryland river channels: the Northern Plains of arid central Australia. Geomorphology 34: 33-54.

Tooth S. (2005). Splay formation along the lower reaches of ephemeral rivers on the Northern Plains of arid Central Australia. J. Sediment. Res. 75: 636-649. 